\title{
Considerations Concerning French Urban Influence on Spanish Colonial Cities on the Island of Cuba
}

\author{
Juan Ramón Jiménez Verdejo*¹, José María Cabeza Laínez², José Manuel Almodóvar Melendo ${ }^{3}$ \\ and Shuji Funo ${ }^{4}$ \\ ${ }^{1}$ Lecturer, Graduate School of Environmental Planning, University of Shiga Prefecture, Japan \\ ${ }^{2}$ Professor, School of Architecture, University of Seville, Spain \\ ${ }^{3}$ Lecturer, School of Architecture, University of Seville, Spain \\ ${ }^{4}$ Professor, Graduate School of Environmental Planning, University of Shiga Prefecture, Japan
}

\begin{abstract}
This paper analyzes the French urban influence on cities created by Spaniards on the island of Cuba from the $16^{\text {th }}$ to $19^{\text {th }}$ century. Due to its geographical location, the island of Cuba acquired great influence from the American and European continent during the Spanish Colonial period.

The study was accomplished through the recompilation of the principal 58 cities created in Cuba during the colonial period, the analysis of their different urban types and the evaluation in several cities of the main characteristic of their French influence.

The evolution of the Hispanic-French relationship and the historical events that affected the Caribbean took place on many cities created during the last century of the colonial period. This is evident in the variations in their urban structure and block divisions.
\end{abstract}

Keywords: Spanish-American city; colonial city; Cuba; urban typology; French urban

\section{Introduction}

The Spanish colonization of the Americas began with the arrival of Christopher Columbus in 1492, and over three centuries the Spanish Empire was expanded from small early settlements in the Caribbean to the American continent.

Through its geographical situation, the island of Cuba played an important role in commercial relations between the American and European continents. During the mid-16 $6^{\text {th }}$ century La Havana was the third city and the first port of the New World.

Therefore, the island of Cuba became the Spanish colony which was most open to the influences of the main European nations with interests in the American continent, mainly France. These influences can be clearly seen in the architecture and urbanism of some Cuban cities.

The purpose of this study is to analyze the quantity and main characteristics of the French influences on the urban design of the Spanish Colonial cities on the island of Cuba.

\footnotetext{
*Contact Author: Juan Ramón Jiménez Verdejo, Lecturer, University of Shiga Prefecture, Graduate School of Environmental Planning, 2500, Yasaka-cho, Hikone-shi, Shiga-ken, 522-8353 Japan

Tel: +81-749-29-0987 Fax: +81-749-29-0987

E-mail: juamra@gmail.com

(Received October 8, 2008 ; accepted April 13, 2009)
}

\section{Methodology}

1) A Study of the urban evolution on the island of Cuba from the summary of historical and graphic information on the main 58 cities created in Cuba until the end of the $19^{\text {th }}$ century. The cartography of the AGI (The Archive of the Indies in Seville) has been used as the main database ${ }^{1}$, also the cartography of the National Archive of La Havana, as well as its photographic area and historical documentation belonging to this colonial period.

2) Based on Considerations on Typology of the City Model described in the Spanish Colonial City Map and Considerations on the Typology of the Spanish Colonial City Model in Cuba ${ }^{2}$, analysis and classification of the different urban types of 48 out of 58 cities created on the island of Cuba until the $18^{\text {th }}$ century ${ }^{3}$.

3) Analysis of the main urban characteristics of the cities with the greatest French influence on the Island of Cuba.

\section{Historical Considerations Concerning the Colonial Period of the Island of $\mathrm{Cuba}^{4}$}

The conquest of the island of Cuba by Spaniards began two decades after Columbus's first trip to America. Diego Velázquez (one of the richest Spanish colonists), began the recognition and conquest of the territory of the island of Cuba in 1510.

The Spaniards founded seven villages with the 
objective of controlling the conquered territory: Asunción of Baracoa (1512), Bayamo (1513), Trinidad (1514), Sancti Spíritus (1514), San Cristóbal de La Havana (1514), Puerto Príncipe (1515) and Santiago de Cuba (1515) as the government's headquarters. From these establishments the conquerors began the exploitation of resources of the Island (Fig.1.).

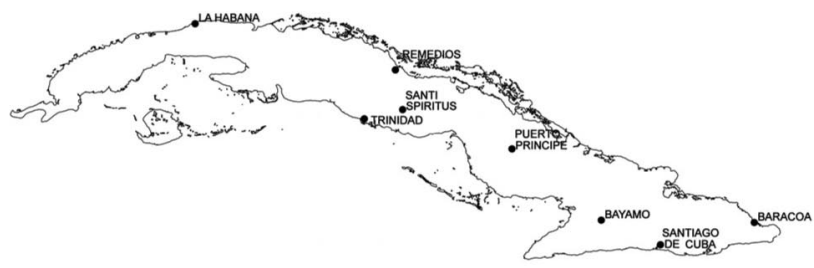

Fig.1. The First Seven Spanish Villages on the Island of Cuba

The economy was based on the work of the natives by the encomienda ${ }^{5}$ system. In the first years of the colony the main economic activity was the extraction of gold. However, the quick reduction of gold and indigenous population (including the Spanish population which left the island to conquer the American continent) produced a change in the economic system, and cattle raising became the main economic source of Cuba.

Salted meat and leather were the main goods which contributed to the overseas commercial circuits during the Spanish empire. This imperial trade was developed as a closed monopoly controlled by the Casa de la Contratación (The House of Trade) of Seville. The interests of other European nations in this trade brought corsairs from France, Holland and England (such as Jacques de Sores, Francis Drake and Henry Morgan) who attacked the Caribbean area, captured ships and plundered cities and towns. For more than a century, the island of Cuba was one of the main targets ${ }^{6}$. To protect its trade, the Spanish big fleets should arrive at the port of La Havana, which is strategically located at the beginning of the current Gulf of Mexico.

At the beginning of the XVII century, the island of Cuba had 30,000 inhabitants. The economic activity grew slowly and was diversified with the development of the cultivation of tobacco and the production of cane sugar. Gradually, new towns far from the coasts were created, and the original seven villages grew in size.

With the ascension of King Felipe V (Philippe $d^{\prime}$ Anjou, grandson of the French King Luis XIV) to the Spanish throne in 1700, the Borbón dynasty carried out a modernization of its mercantilist. In this case, the Spanish Crown promoted the monopolization of tobacco production in Cuba.

During the 18th century, America was involved in successive wars with the main European nations, which greatly affected Cuba. But the most transcendent was the Seven Year War (1756-1763) which surrendered the city of La Havana in eleven months (August 1762 to July 1763) to the English military. From the reign of King's Carlos III, its Enlightenment ministers adopted several initiatives to favor the progress of the country. One of these initiatives was the recruitment of new scientists from foreign cities, which were mostly French (Louis Joseph Proust, Francis Chavaneau and Charles Lemaur $)^{7}$. Concurrently, the strengthening of defenses and construction of several public and religious buildings were carried out as major projects on the island.

The external trade of the Island was enlarged, while at the same time the interior communications were improved and new towns created, with the participation of French Engineers (M. De Valliére, M. Ricaud de Targale, Fresnel and Henri Lepante, Stephane Lafayette, José Tantete, Carriere de La Tour and Julien

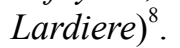

The war of independence of the Thirteen English Colonies of North America ${ }^{9}$ (1775-1783) also contributed to the prosperity of the island of Cuba. During this time, Spain, despite being a participant in the conflict, approved trade between Cuba and the rebel colonists. The economy of the island, which was based on sugar and coffee, grew dramatically. However, this economic progress was due to the increase of slavery over a period of 30 years from 1790, compared with the previous 150 years when more African slaves were brought to the island. In addition, thousands of Spaniards and French fugitives arrived in Cuba from Haiti during the revolution between 1791 and 1804 .

During the $19^{\text {th }}$ century the main European nations (Spain, France, England and Holland) established a colonial system by which control the world (Fig.2.). France founded colonies in much of eastern North America, on a number of Caribbean islands, and in South America (Quebec and Montreal in Canada; Detroit, St. Louis, Mobile, Biloxi, Baton Rouge and New Orleans in the United States; and Port-au-Prince and Cap-Haïtien in Haiti).

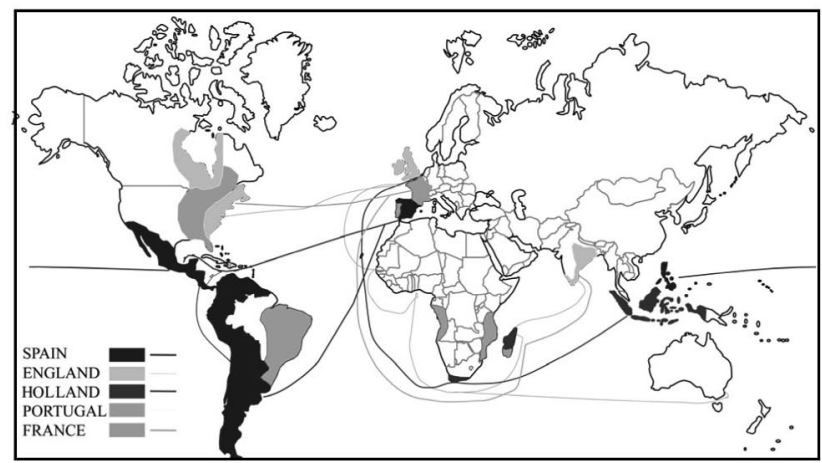

Fig.2. Colonial World System in 1850.

(Source: E.Crevari, L.Strazza, G.Dyszel)

\section{Types of Spanish Colonial Urban Cities during the $16^{\text {th }}$ and $19^{\text {th }}$ Centuries}

A database for 47 out of 58 main cities (Fig.3.) was created to analyzing the principal Spanish Colonial 
Cities between the $16^{\text {th }}$ and $19^{\text {th }}$ century on the island of Cuba by the re-compilation of information through maps and a bibliography ${ }^{10}$. A study of the grid plan and block was made possible in order to classify 5 different types of urban design (Fig.4.):

1) Cities with an irregular grid (8 cities):

1.1 Six cities created in the $16^{\text {th }}$ century: Baracoa (1510), Bayamo (1513), Remedios (1514), Santi Spiritus (1514), Puerto Príncipe (1515), and Trinidad (1515). Baracoa and Trinidad are coastal cities. Trinidad has a square-shaped plaza while Bayamo, Santi Spíritus and Puerto Príncipe have rectangular shaped plazas. The city of Remedios has an irregular shaped plaza, with two churches, one of them located in the main area.

1.2) One city created in the $17^{\text {th }}$ century: Melena del Sur (1650), with a square shaped plaza.

1.3) One city created in the $18^{\text {th }}$ century. San Juan $y$ Martinez (1750) with an irregular shaped plaza.

2) Cities with Regular Grid, Imperfect Square and/or Rectangular Blocks (16 cities).

2.1) Three cities created in the $16^{\text {th }}$ century: $L a$ Havana (founded in 1514 by Pánfilo de Naváez) and Santiago de Cuba (founded by Diego Velázquez in 1515) are coastal cities. The Plaza and surrounding blocks were drawn as a perfect square, while the growth of the city resulted in the square grid being modified to squares and rectangular blocks. And the city of Hoguin ${ }^{11}$ (founded by Francisco García
Holguin in 1523).

2.2) One city created in the $17^{\text {th }}$ century: Villa Clara (1692), with a rectangular shaped plaza.

2.3) Eight cities created in the $18^{\text {th }}$ century: Jiguani (1701), Juan Alberto Gómez (1747), Guaimaro (1750), Las Tunas (1750), Sagua de Tanamo (1750), Guisa (1766), Pinar del Rio (1773) and San José de las Lajas (1778).

2.4) Four cities created in the $19^{\text {th }}$ century: Manzanillo (1805), Colón (1818), Gibara (1820) and Nueva Gerona (1827).

3) Cities with Regular Grid and perfect square blocks (8 cities).

3.1) One city created in the $17^{\text {th }}$ century: Santiago de las Vegas (1694). In the AGI cartography there are two different city plan designed by José Tantete in $1747^{12}$ and $1756^{13}$, both with perfect square grid.

3.2) Four cities created in the $18^{\text {th }}$ century: Güines (1735), planned with aperfect square grid designed by José del Pozo Sucre and Luis Huet $^{14}$ in 1784; Jaruco (1770), designed by Luis Huet in 1773, its plan ${ }^{15}$ is based on a perfect square grid which was the current city design, but the dimensions of the plaza have been reduced by half, Nuevitas (1775), which was a rare plan designed by Vicente Sebastián Pintado in $1819^{16}$; and, Cumanayagua (1800).

3.3) Three cities created in the $19^{\text {th }}$ century: Nueva Paz (1802) the plan of which was designed by Rafael Gómez Ronband in $1806^{17}$, Guantánamo

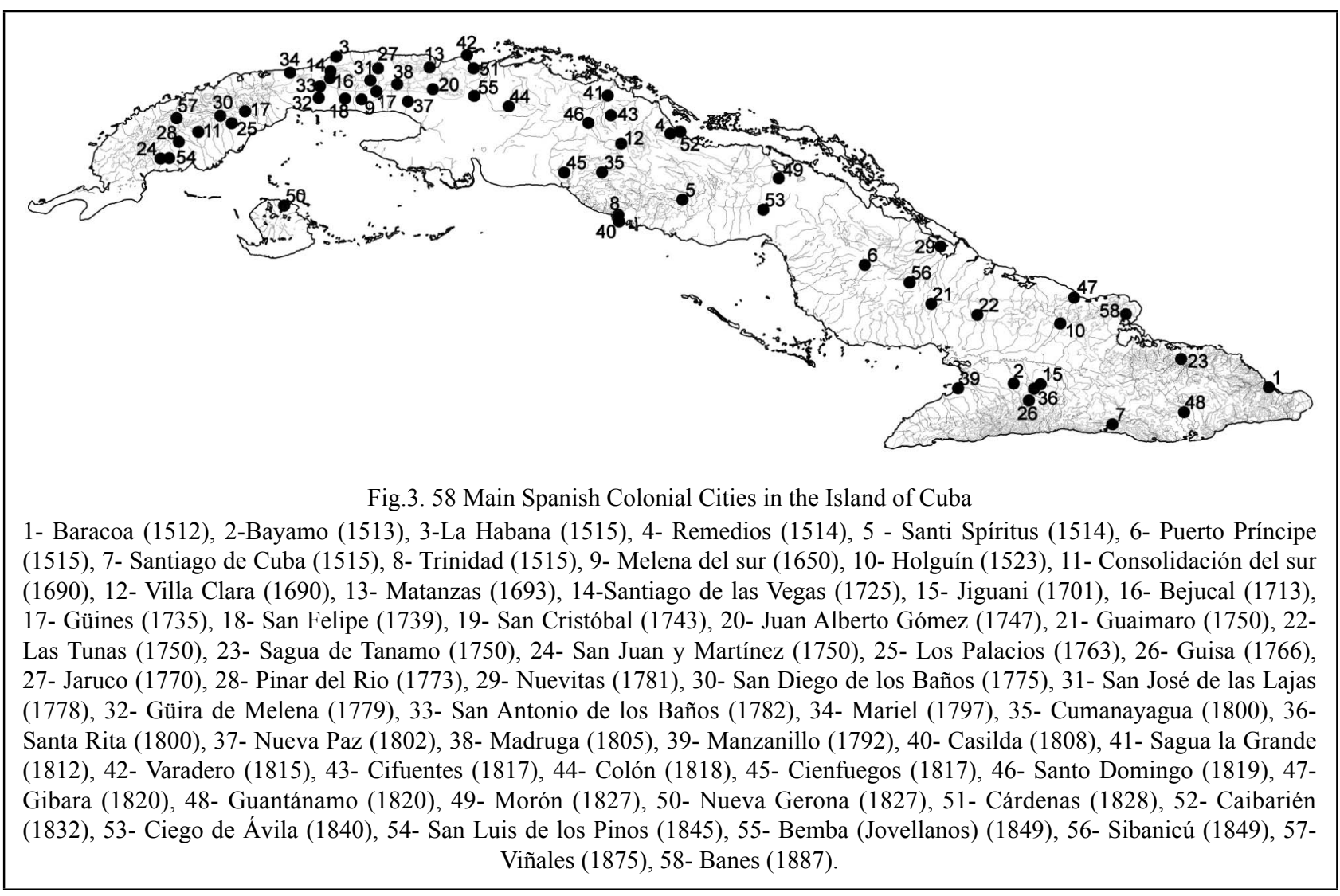




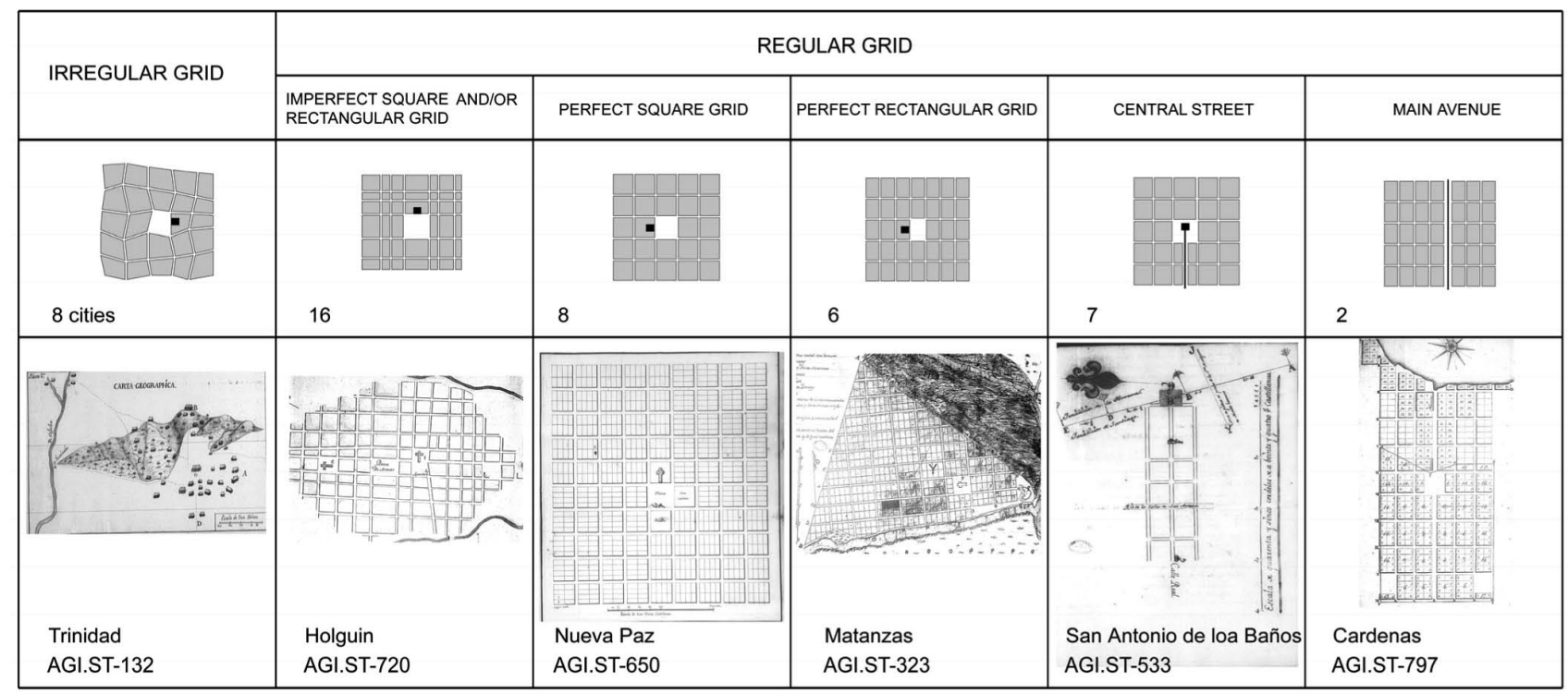

Fig.4. Types of Spanish Colonial Urban Cities on the Island of Cuba

(1820) and Caibarién (1832).

4) Cities with Regular Grid and Perfect Rectangular blocks (6 cities).

4.1) One city in the $17^{\text {th }}$ century: Matanzas ${ }^{18}(1693)$.

4.2) Two cities in the $18^{\text {th }}$ century: Bejucal (1713) and San Felipe $e^{19}$ (1739).

4.3) Three cities in the 19th century: San Luis de los Pinos (1845), Bemba (1849) and Viñales (1875).

5) Cities with Regular Grid and a Central Street (7 cities)

Los Palacios (1763), San Diego de los Baños (1775), Güira de Melena (1779), San Antonio de los Baños (1784), Madruga (1805), Sagua la Grande (1812) and Cifuentes (1817).

6) Cities with Regular Grid and a Main Avenue (2 cities)

Cienfuegos (1819) and Cárdenas $^{20}$ (1828).

\section{The Main French Influence on Cuban Cities}

Urban plans in the cartography of the AGI were analyzed and it was found that the most common urban group model used by the Spaniards on the Americancontinent was apparently a simple plaza (with

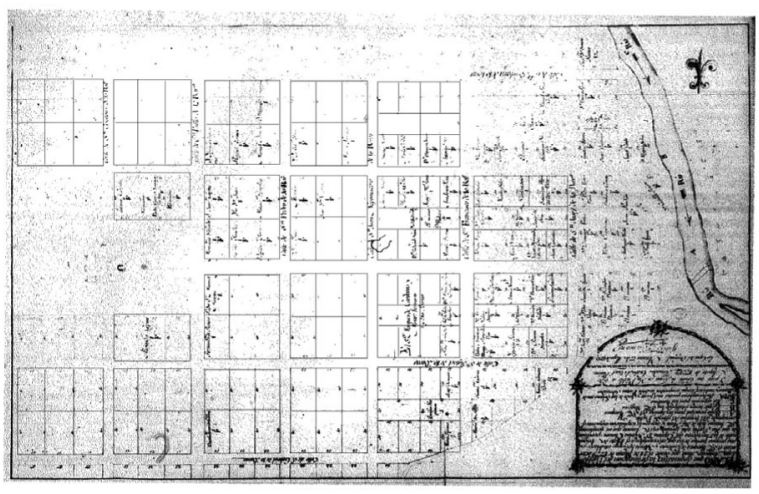

Fig.5. San Antonio de los Baños. Guillermo Duncan, 1779, AGI-Santo Domingo 567

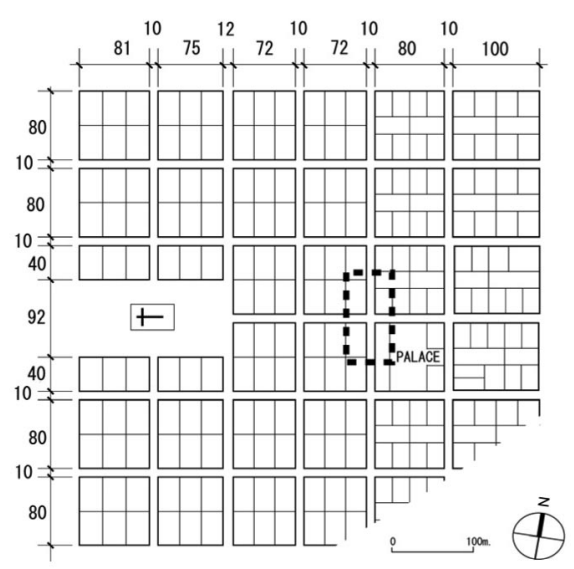

Fig.6. Plan of San Antonio de los Baños

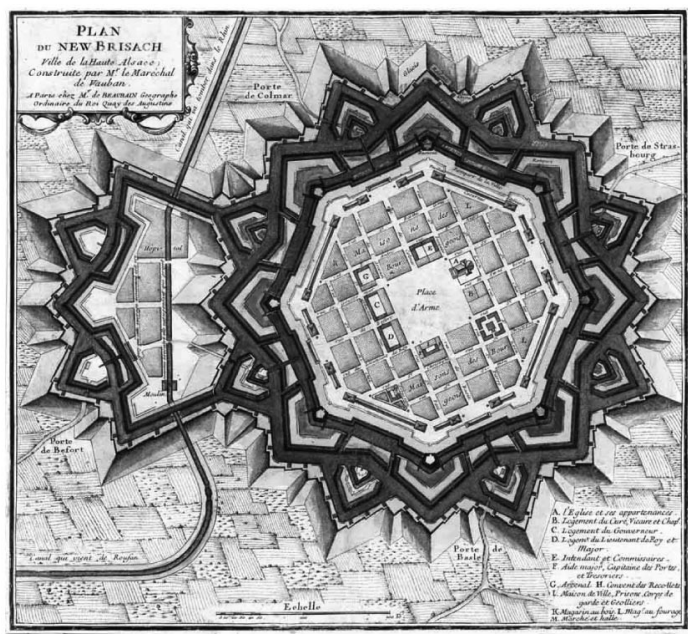

Fig.7. Neuf-Brisach (1699-1702), Anonimus, Musée des Plans-Reliefs, Paris

8 streets in its corners) and a regular grid of square or rectangular blocks ${ }^{21}$. However, through the French urban influence, new design elements were introduced in the traditional Spanish Colonial urban models. These 


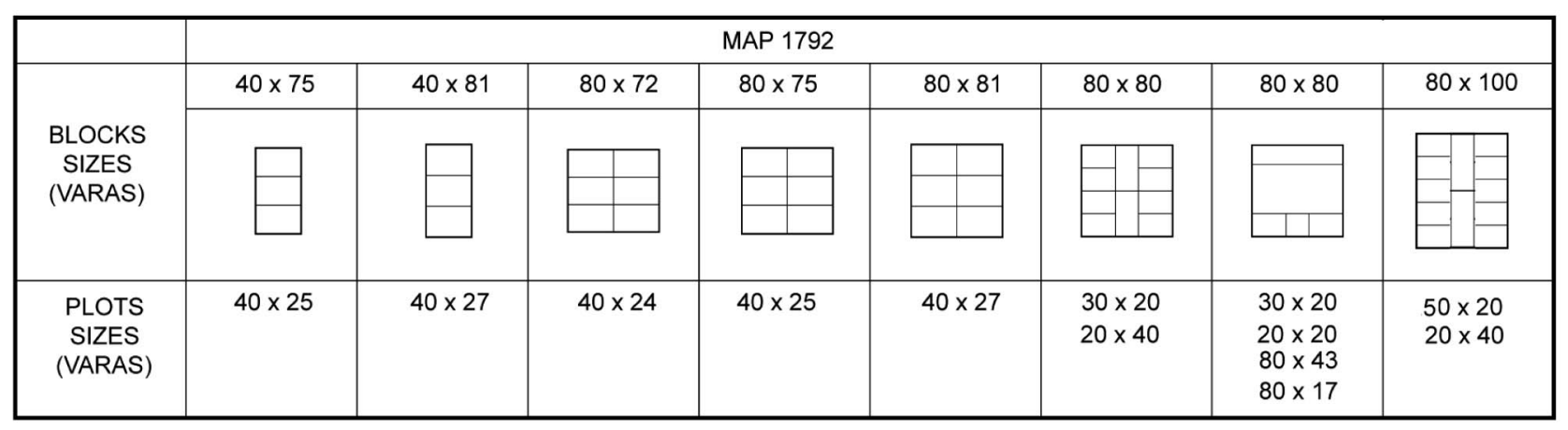

Fig.8. Pattern Blocks of San Antonio de los Baños. (1 vara $=0.848$ meter)

fundamental elements were the use of an axis in the formation of a main street or avenue; the localization of the squares; and the subdivision of the blocks.

These new contributions to the urban design are evident in cities like San Antonio de los Baños, Cienfuegos, Santiago de las Vegas, Cárdenas or Nuevitas.

a) San Antonio de los Baños: After the foundation of San Antonio de los Baños in 1784, the distribution of lots to work the land and build houses resulted in a great increase in the population. Recent inhabitants were French colonists that abandoned Haiti during the Slave Revolution (1791 1803). French emigrants were among the powerful farmers that were accepted on the island with the approval of Spain since they brought capital investment and a technically superior preparation that increased production. The plan of San Antonio de los Baños formed a central axis (the main street) that connects two plazas (Figs.5., 6.). This type of plan is unusual in Spanish Colonial cities, and unique on the island of Cuba, and no similar plan exists in the whole cartography of the AGI that corresponds to the entirety of the American continent. Also, the division of plots is another evidence of the French influence in the city of San Antonio de los Baños (Fig.8). The division of plots with eight smaller plots on the sides and two (or four) longer plots in the middle of the block pattern was created around 1698 by the French military engineer Vauban (1633-1707), for the fortified town of Neuf-Brisach (1699-1702) in the French province of Alsace (Fig.7). This pattern is used in several plans of French overseas settlements such as New Orleans (1728), Pourt-au-Prince (1749) or San Marc (1785).

b) Cárdenas: The current plan of Cárdenas city was designed in 1830 by Spanish surveyor Andrés José Portillo, who studied in North America. The plan of Cárdenas city was a regular grid of rectangular blocks with central axis (the main avenue) that crosses the entire city. The streets were designed with a width of $14 \operatorname{varas}^{22}$ and the main avenue with a width of 20 varas.

The grid was formatted with blocks of 80 varas $\mathrm{x}$ 120 varas (blocks of 8 lots) and blocks of 80 varas $\mathrm{x} 90$ varas (blocks of 6 lots). However the division
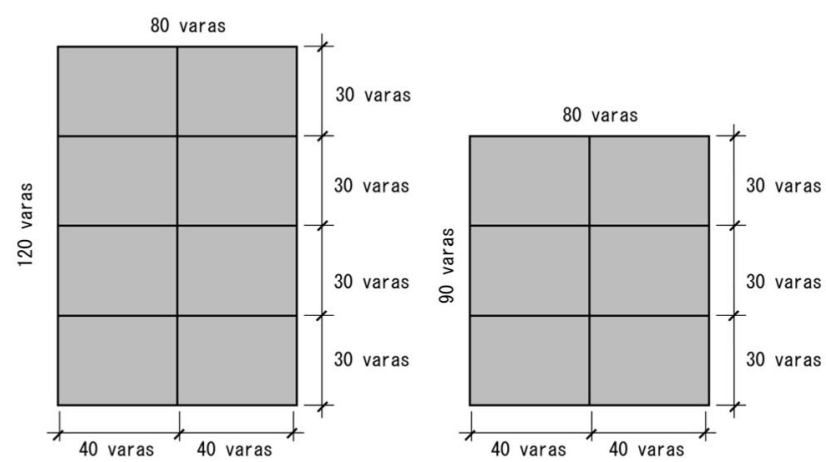

Fig.9. Block Pattern of Cárdenas

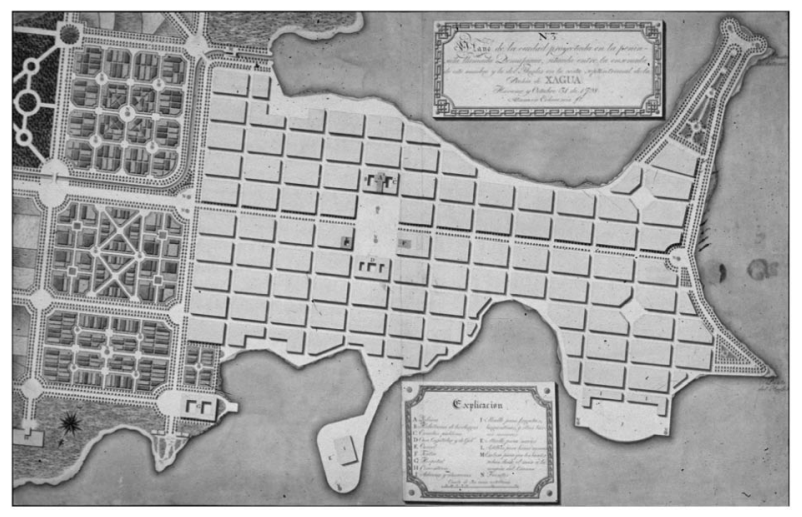

Fig.10. Cienfuegos. Anastasio Echevarria. 1798. Naval Museum, Spain

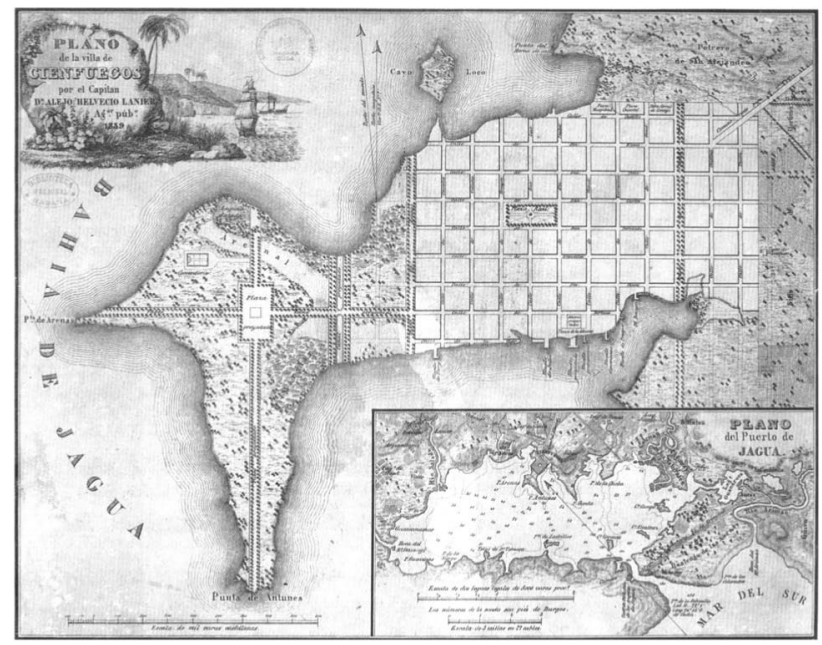

Fig.11. Cienfuegos, Alejo Helvecio Lanier, 1839, BN Jose Marti 
of blocks by lots with the same area and dimensions was typical in Spanish Colonial cities,. In the case of Cárdenas city the lots have 1200 square varas, 30 varas in front of the street and 40 varas in depth (Fig.9.).

c) Cienfuegos: The first plan of Cienfuegos was designed by the Spaniard Anastasio Echevarria in $1798^{23}$ during the expedition of The Real Commission of Guantánamo. This first plan (Fig.10.) was designed with a regular grid of rectangular blocks with central axis (the main avenue) that crosses the entire city. However the current plan of the city of Cienfuegos was designed by Juan Luis Lorenzo D'Clouet in 1819. D'Clouet was a rich French colonel who emigrated from Louisiana. In March of 1817 D'Clouet introduced a project to Spanish General Captain José Cienfuegos to colonize the bay of Jagua. The Spanish Court accepted the project in October of 1817 and authorized the foundation of the city. In April of 1819, $D^{\prime}$ Clouet started the colonization with 46 colonists coming from Bordeaux (France), the French doctor Domingo Monjeni and the French surveyor Dubrog. In the year 1820, 382 colonists arrived in the city (50 from Philadelphia, 74 from Baltimore, 13 from New Orleans, 12 from Lousiana and 229 from several locations of the island of Cuba. The main characteristic of the plan of Cienfuegos is the creation of a main avenue, which was not aligned with the main plaza. The regular grid was formed by square blocks of 100 varas. The streets were designed with a width of 15 varas and the main avenue with a width of 30 varas (Fig.11.).

The division of plots was the same as that of the French pattern of Vauban with eight smaller plots on the sides and two longer plots in the middle of the block (Fig.12.).

d) Santiago de las Vegas: The plan of Santiago de las Vegas was designed by José Tantete. Colonel José Tantete y Dubruiller was born in Orchies (Douai, France). From 1742 Tantete was colonel of engineers in La Havana. He worked on several urban designs such as the Plaza de San Ignacio en La Havana ${ }^{24}$, Plan of Santiago de las Vegas ${ }^{25}$, city of Horcón ${ }^{26}$, the Bay of Nipe $^{27}$ and the Fort of Jagua ${ }^{28}$.

For the first plan of Santiago de las Vegas, Luis Huet designed an original block pattern based on eight plots of the same shape and dimensions in a rotary pattern (Fig.13.). For the second plan of Santiago de las Vegas, Huet designed a different pattern block of eight plots with different shapes and dimensions, but with the same area (Fig.14.). The current division plots of Santiago de las Vegas is based on this pattern.

The French influence is also clear in urban designs made by Spaniards, for example the plan of the city of Nuevitas, made in 1819 by Vicente Sebastián Pintado. This is a plan of regular grid and rectangular and square blocks. The divisions of the blocks are based

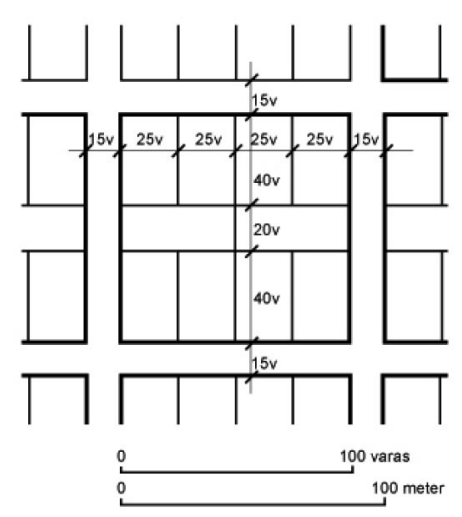

Fig.12. Pattern Blocks of Cienfuegos. (1 vara $=0.848$ meter $)$

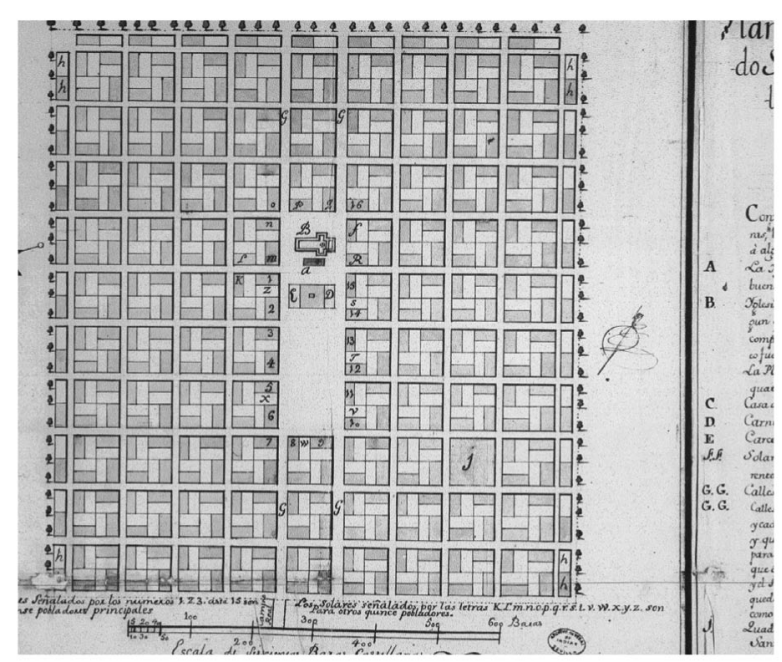

Fig.13. Santiago de las Vegas, José Tantete, 1747, AGI. Santo Domingo 324

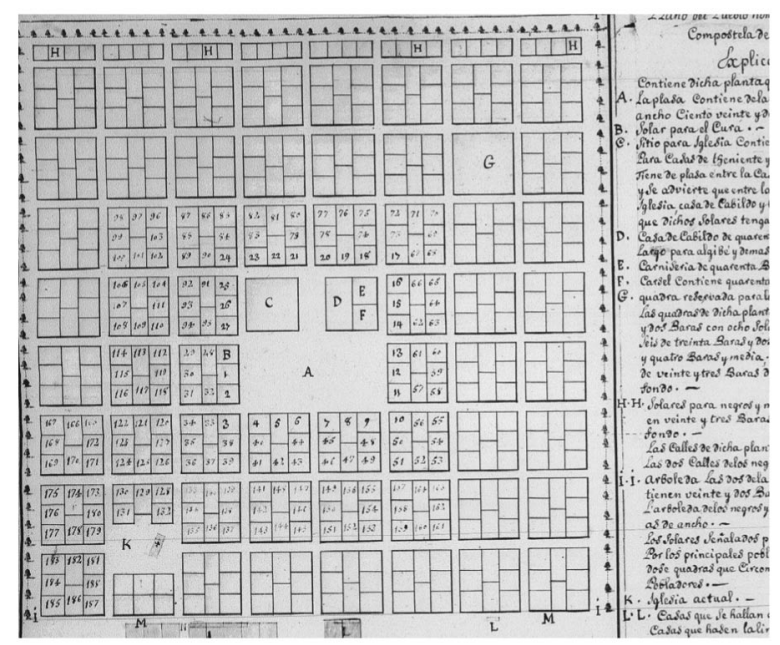

Fig.14. Santiago de las Vegas, José Tantete, 1756, AGI. Santo Domingo 302

on the pattern of Vauban. From the corner of the main plaza four diagonal avenues connect four secondary plazas. Rarely were any churches designed in all of these 5 plazas. This plan was not carried out, and the current drawing remains as a perfect square grid with no plaza with church. 


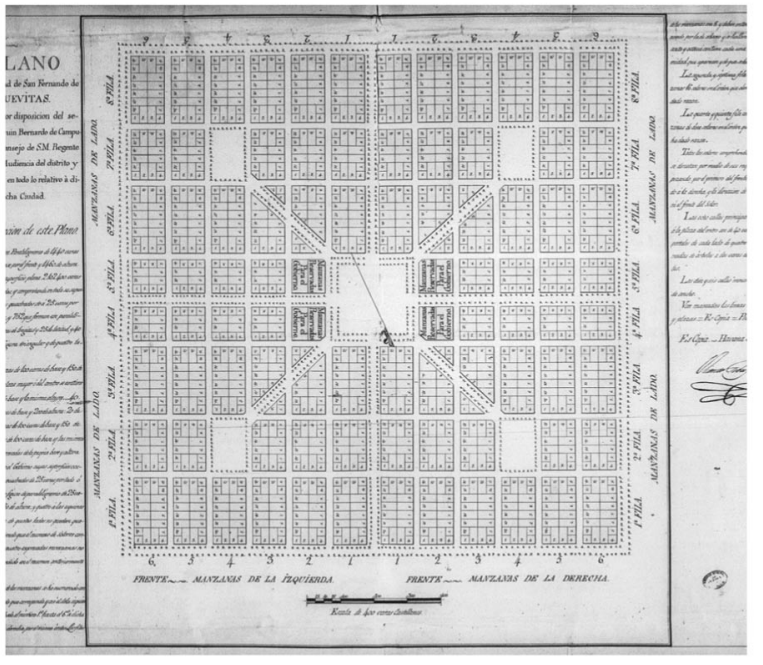

Fig.15. Nuevitas, Vicente Sebastián Pintado, 1819, AGI- Santo Domingo 731

\section{Conclusion}

After a geometric analysis of the maps of the Archivo General de Indias, it is possible to verify that $60 \%$ of the existing Spanish Colonial Cities were created based on common geometric characteristics. Nevertheless there are a great number of plans with interesting variations of urban design. According to an analysis of the maps of the AGI, Cuba has more cities with variations in urban design. This is because, as a Spanish colony on the American continent, it recived more influence from ideas from Europe up until the $19^{\text {th }}$ century.

French urban influence on Spanish Colonial cities on the island of Cuba was carried on directly by the designs of French engineers and with designs indirectly introduced by Spanish engineers with the formation of French academics.

In the mid- $17^{\text {th }}$ century, the Spanish crown programmed the formation of Spanish engineers by bringing in foreign scientists, the majority of whom were from France. This influence is more evident in urban designs on the island of Cuba in the $19^{\text {th }}$ century. During this time, new urban elements were introduced in the classic Spanish grid, such as central axes and avenues, combinations of plazas, variations on the regular grid and on new patterns of the block division.

\section{Acknowledgements}

The authors express their appreciation to Professor Julio César Pérez of La Havana University, Professor Kyota Yamada of Tottori Environmental University, the Archive of the Indies and the Department of Reproduction Archives of the Ministry of Education and Culture of Spain.

\section{References}

1) The Authors have been conducting field research on the 'Origin, Transformation, Alteration and Conservation of the Urban Space of Colonial Cities' since 1999. The study of colonial cities has been accomplished based on the analysis of old maps corresponding to the colonial Spanish period. As a cartographic database, 7,152 images and maps from the AGI (The Archive of the Indies in Seville- Archivo de Indias de Sevilla), are used for analysis.

2) a) Considerations on Typology of the City Model described in the Spanish Colonial City Map, Juan Ramón Jiménez Verdejo, Shuji Funo, Takahito Saiki, Journal of Architecture and Planning., AIJ, No. 616, 91-97, June 2007. b) Considerations on Typology of the Spanish Colonial City Model in Cuba, Juan Ramón Jiménez Verdejo, Shuji Funo, Kyota Yamada, Journal of Architecture and Planning., AIJ, No. 623, pp.117-123, January 2008.

3) Other authors' publications on Spanish Colonial Cities in Cuba: a) Considerations on the urban formation and block division of Cárdenas (Cuba), AIJ, No73-633, November 2008. b) Considerations on the urban formation and block division of San Antonio de los Baños (Cuba), AIJ, No73-629, July 2008. c) Considerations on urban formation and block division of Cienfuegos (CUBA), AIJ, N73-626, April 2008. d) Hatos and Corrales, Considerations on the Spanish Colonial Territory Division System in Cuba, AIJ, 73-625, March 2008. e) Considerations on urban formation and block division of Nueva Paz (Cuba), AIJ, 73-623, January 2008. f) The Hatos and Corrals: Considerations on the Spanish Colonial Territorial Occupation System in Cuba, JAABE, Vol.7(2008), No1, 23-30, May 2008. g) Study on formation, transformation, localization and conservation of Spanish colonial cities: urban formation and typology of colonial cities in Cuba, Journal of Housing Research Foundation, No.34 (2007), March 2008.

4) For Historical Considerations concerning the Colonial period of the Island of Cuba the follow bibliographic sources have been used:

a) Catálogo de los Mapas, planos, croquis y árboles genealógicos existentes en el Archivo Nacional de Cuba. Tomos I, II, III, IV, V, VI. Archivo General de Cuba. 1961. b) Catalogo de mapas y planos de Santo Domingo. Julio González. Madrid 1973. c) Historia de Cuba. Ricardo V. Rousset La Habana. 1918. d) Las primeras ciudades Cubanas y sus antecedentes urbanísticos. Guillermo de Zendegui. Cuban National Heritage and Ediciones Universal. Miami. 0-89729-836-5. e) 500 años de construcciones en Cuba. Vuevas Toraya, Juan de las. Cuba. Chavin. Madrid. 2001.84-607-3159-6. f) Atlas demográfico Nacional. Cuba. Comité de estadísticas. Instituto cubano de geodesia y cartografía. La Habana. 1985. Juan de las Cuevas Toraya. Servicos gráficos y editoriales. La Habana 2001. 84-607-3159-6. g) Geografía de Cuba. Levi Marrero. La Habana. 1951. h) Cuba Ilustrada. Real comisión de Guantanamo 1792-1802. Quinto Centenario. 84-7782-166-6. i) La arquitectura colonial cubana. Weiss, Joaquin E... Junta de Andalucia: C.O.P.T. Instituto cubano del libro. Madrid. 1997.84-8095-083-8. j) Huellas Francesas en el occidente de Cuba (siglos XVI-XIX). Ronaldo Álvarez Estévez. Ediciones Boloña. Editorial José Martí. La Habana 2001. 959-09-0195-6.

5) System of Encomienda: economic and social organization based on the grouping of aborigines by the Spanish colonists. The colonists should civilize and evangelize them. The aborigines should work for the colonists. Estrella Rey, Esbozo etnohistórico del siglo XVI temprano (Cuba: 1511-1533). Anuario de Etnología 1988, Ed. Academia, La Habana, 1988. pp.17-18. 
6) The most famous Corsairs who attacked the island of Cuba are the following: a) From France: Jean- François de la Roque de Roberval in 1546, Jacques de Sore in 1554, François Leclerc in 1554, Jacques de Sores in 1555, Richard Hawkins in 1586, Gilberto Girón in 1604 and Jacques Jean David Nau in 1667. b) From England: John Hawkins in 1565, Francis Drake in 1596, Christopher Mings in 1662 and Henry Morgan in 1668. c) From Holland: Pieter Pieterszoon in 1628 and Edward Mansveldt in 1665.

7) The French scientist Francis Chavaneau created in 1777 a profitable technique for the purification of platinum. He was the first chemistry professor of the Real Seminario Patriótico de Vergara. (Spain). The French scientist Louis Joseph Proust, by recommendation of Lavoisier (father of modern chemistry), took charge in 1786 of chemistry and metallurgy teaching at the Academy of Artillery of Segovia (Spain). (Furio Mas, Padilla martínez, "La evolución histórica de los conceptos científicos como prerrequisito para comprender su significado actual: el caso de la cantidad de substancia y el mol", Didáctica de las Ciencias Experimentales y Sociales, 17, 2003,55-74). "Carlos Lemaur was a French engineer, recruited by the Court of Fernando VI in 1750..." Manuel Esteban García, Carlos Lemaur, un ingeniero excepcional en la ilustración, (Manuel Esteban García, Cimbra: Revista del C. I. T.O.P., ISSN 0210-0479, No. 353, 2003 , pp.50-53 ).

8) M. De Valliere, M. Ricaud de Targale: French engineers. They made the design of the Castillo of San Carlos de la Cabaña in La Habana built between 1763 and 1774...Stéphane Lafayette and Julien Lardiere: French engineers who arrived in Cuba from Haiti in 1804. Fresnel and Henri Lepante, French engineers. who desgned the tower of Castillo del Morro in La Habana, which was finished in 1844. Fresnel also designed the lighthouse of this castle. (Huellas Francesas en el occidente de Cuba (siglos XVIXIX). Ronaldo Álvarez Estevez. Ediciones Boloña. Editorial José Martí. La Habana 2001. isbn 959-09-0195-6.86,). Carriére de La Tour, Arsène: French engineer who designed in 1791 the first bridge over the Almendrades river in Puentes Grandes (Cuba). (500 años de construcciones en Cuba. Vuevas Toraya, Cuba. Chavin. Madrid. 2001.84-607-3159-6.)

9) Thirteen English Colonies of North America: New Hampshire, Massachussets, Nueva York, Rhode Island, Connecticut, Nueva Jersey, Pennsylvania, Delawere, Maryland, Virginia, North Carolina, South Carolina and Georgia.

10) The cities database has been gathered from the following documents:

-Maps: a)Maps of AGI cartography. Mapas y planos de Santo Domingo. b) Satellite photographs Google earth. c) Maps of Naval Museum. Spain. d) Atlas Nacional de Cuba, Academia de ciencias de Cuba y la URSS. 1970. e) Geocommunity GIS data. -Bibliography: see Reference 4).
11) Map of Holguín, Francisco de Zayas,1816, AGI. MP ST.-720.

12) Santiago de las Vegas, José Tantete, 1747, AGI. MP ST.- 224.

13) Santiago de las Vegas, José Tantete, 1756, AGI. MP ST.-302.

14) Plano de San Julián de los Güines y el proyecto de la nueva villa, echo de orden de S.M. por el brigadier e ingeniero director don Luis Huet, José del Pozo Sucre and Luis Huet, AGI. M MP ST.-503.

15) Plano de la nueva ciudad de Jaruco, Luis Huet, AGI. MP ST.-381.

16) Plano de la ciudad de San Fernando de Nuevitas, Vicente Sebastián Pintado, AGI. MP ST.-731.

17) Plano en la figura cuadrada de la ciudad de Nueva Paz, Rafael Gómez Ronbaud, AGI. MP ST.-665.

18) Plano de Matanzas, J. F. y Sotolongo, 1764, AGI. MP ST.-323.

19) Plano de la ciudad de San Phelipe y Santhiago, Bartolomé Lorenzo de Flores, 1751, AGI. MP ST.-282.

20) Plano de la población del puerto de Cárdenas, Andrés José del Portillo, 1830, AGI. MP ST.-797.

21) Juan Ramón Jiménez Verdejo, The Spanish-American City Study of the urban model used by José de Escandón to create the Colony of Nuevo Santander, Ph. D Dissertation, 2005.

22) 1 Cuban vara $=0.848$ meter

23) Naval Museum. Spain. MN.MS 552. MN-19-D-5.

24) Plano plazuela San Ignacio, José Tantete, 1749, AGI. MP ST.-260.

25) Idem references 9 and 10.

26) -Plano de pueblo de N. Sra del Rosario de Horcón. José Tantete, 1749, AGI. MP ST.-259., - Plano de las tierras de don S. Muñoz en el Horcón de M. González, José Tantete, 1758, AGI. MP ST.-313.

27) -Plano del puerto de Nipe. José Tantete, 1754, AGI. MP ST.-296.

28) Plano del Fuerte de Nra. Sra. De los Ángeles de Jagua en la ysla de Cuba, AGI. MP ST.- 373 